\title{
Experimental evaluation of traction and coupling properties of snowmobile motor vehicles
}

\author{
Evgeny Klubnichkin ${ }^{1, *}$, and Vladislav Klubnichkin ${ }^{1}$ \\ ${ }^{1}$ Bauman Moscow State Technical University, Department of Wheeled Vehicles, 105005 Moscow, \\ Russian Federation
}

\begin{abstract}
The article demonstrates the results of the experimental estimate of the drawbar properties of the oversnow equipment during which parameters and indicators allowing for their use during designing of new generation of oversnow vehicles have been determined. This work demonstrates the results of the tests in determining maximum drawbar pull, determining motion resistance force with the arrested and released brake of the Russkaya Mekhanika's oversnow vehicles, models RM Buran Leader, RM Tayga Varyag 550, RM Tayga Patrul 800 SWT, RM Vector 551i and over companies' oversnow vehicles, models BRP Lynx Xtrim Commander 800 E-TEC, Arctic Cat Pantera 7000 XT LTD, Polaris 800 Titan Adventure 155 .
\end{abstract}

\section{Place of test}

The tests to determine drawbar properties of the oversnow equipment were conducted in vicinity of Rybinsk, Yaroslavl oblast, Russia at the horizontal terrain sections with the maximum slope of $1 \%$.

During the test:

The test site was covered with compacted snow 5 to $7 \mathrm{~cm}$ deep, the snow was uniform along the entire depth, with a temperature of minus $6{ }^{\circ} \mathrm{C}$.

The tests were conducted in dry windless weather at an ambient temperature of minus 6 ${ }^{\circ} \mathrm{C}$, atmospheric pressure of $748 \mathrm{~mm} \mathrm{Hg}$ and air relative humidity of $86 \%$ [1-3].

\section{Measuring equipment}

Weight measuring strain gauge $\mathrm{C} 2-5.0-\mathrm{C} 3$ and digital tension gauge ZET were used as measuring instruments to determine the oversnow drawbar properties including maximum drawbar pull and motion resistance force [4].

Digital dynamometer C2-5.0-C3 represents a stain gauge-based device. The strain gauge is connected in series with the power diagram. Dynamometer C2-5.0-C3 is composed of a weight measuring strain gauge working in tension and compression, a secondary measuring

\footnotetext{
*Corresponding author: klubnichkin@mgul.ac.ru
} 
converter and a connecting cable. Model ZET is used in dynamometer as a secondary measuring converter.

Dynamometers with measuring terminal ZET operating through interface ZET 7174 converter are delivered with software ZETLAB used to present those measurements in the form of real-time measurement process charts.

Dynamometer $\mathrm{C} 2-5.0-\mathrm{C} 3$ is designed to measure tension force (with upper measurement limit of $50 \mathrm{KN}$, accuracy class 2 according to GOST P 8.726-2010).

\section{Determining maximum drawbar pull}

The maximum drawbar pull was determined for the Russkaya Mekhanika's oversnow vehicles, models RM Buran Leader, RM Tayga Varyag 550, RM Tayga Patrul 800 SWT, RM Vector 551i and over companies' oversnow vehicles, models BRP Lynx Xtrim Commander 800 E-TEC, Arctic Cat Pantera 7000 XT LTD, Polaris 800 Titan Adventure 155 equipped with caterpillar tracks with snow grip from 10 to $45.7 \mathrm{~mm}$.

The maximum possible drawbar pull of the oversnow vehicle (within the pull force margins) was determined with the CVT being in first gear range. With that the tested oversnow vehicle was accelerated to reach maximum RPM, and then smoothly slowed down via a cable with a dynamometer stain gauge to a full stop when a tracked running gear was fully slipping $[5,6]$.

The results of the drawbar pull measurement are presented in Table 1.

Table 1. Results of maximum drawbar pull measurement

\begin{tabular}{|c|c|c|}
\hline Oversnow vehicle & $\begin{array}{c}\text { Height of track } \\
\text { snow grip, mm }\end{array}$ & $\begin{array}{c}\text { Maximum drawbar } \\
\text { pull, } \mathbf{N}\end{array}$ \\
\hline RM Buran Leader & 10 & 1975 \\
\hline RM Tayga Varyag 550 & 30 & 2346 \\
\hline RM Tayga Patrul 800 SWT & 30 & 3276 \\
\hline RM Vector 551i & 30 & 3092 \\
\hline BRP Lynx Xtrim Commander 800 E- \\
TEC & 44 & 3786 \\
\hline Arctic Cat Pantera 7000 XT LTD & 35 & $\begin{array}{c}3841-\text { low gear } \\
5978-\text { super low } \\
\text { gear }\end{array}$ \\
\hline Polaris 800 Titan Adventure 155 & 45.7 & 3590 \\
\hline
\end{tabular}

Fragments of the oversnow vehicle tests to determine maximum drawbar pull are presented in Figure 1. 


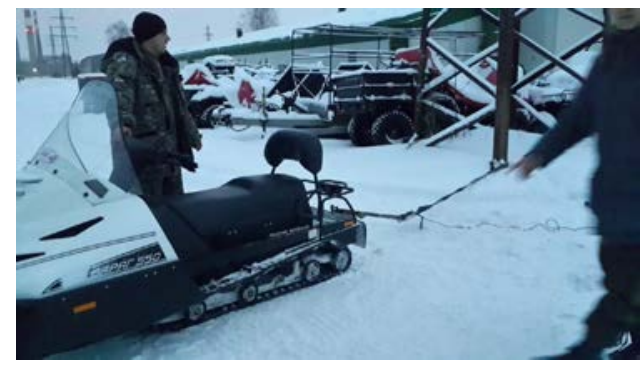

a)

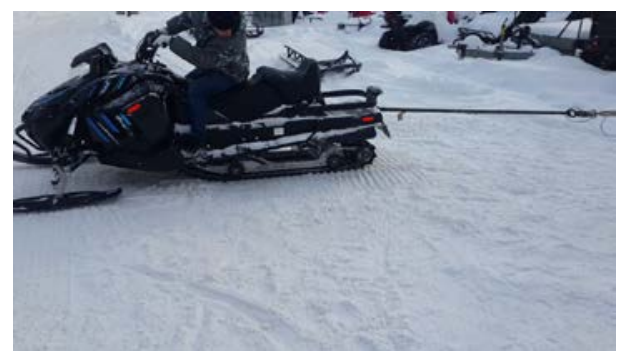

c)

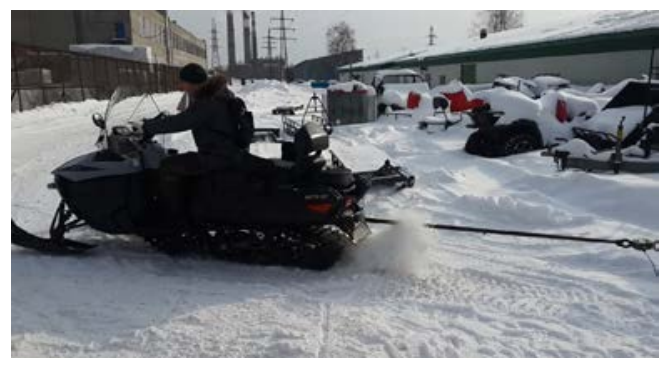

e)

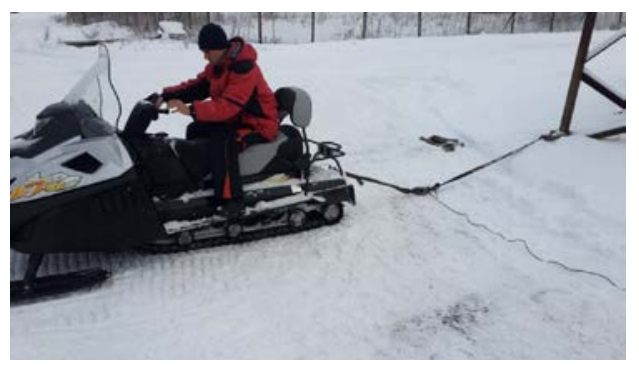

b)

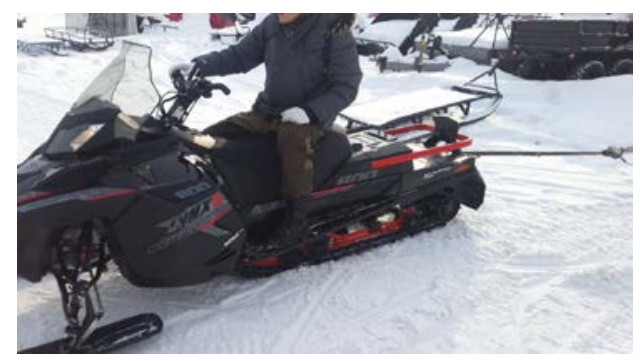

d)

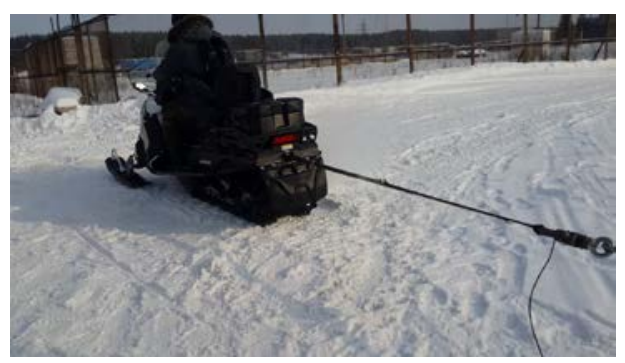

f)

Fig. 1. Fragments of the oversnow vehicle tests to determine maximum drawbar pull: a) RM Tayga Varyag 550; b) RM Tayga Patrul 800 SWT; c) RM Vector 551i; d) BRP Lynx Xtrim Commander 800 E-TEC; e) Arctic Cat Pantera 7000 XT LTD; f) Polaris 800 Titan Adventure 155

\section{Determining motion resistance force}

The motion resistance force was determined for the Russkaya Mekhanika's oversnow vehicles, models RM Buran Leader, RM Tayga Varyag 550, RM Tayga Patrul 800 SWT, RM Vector 551i and over companies' oversnow vehicles, models BRP Lynx Xtrim Commander 800 E-TEC, Arctic Cat Pantera 7000 XT LTD, Polaris 800 Titan Adventure 155.

The motion resistance force was determined by the tested vehicle towing method. The oversnow vehicle was towed with a cable with strain gauge C2-5.0-C3 at a speed of $1 \mathrm{~m} / \mathrm{s}$ by an oversnow vehicle or 4-wheeler, with that the transmission of the tested oversnow vehicle was in neutral gear and brakes either: case 1 - released; case 2 - applied [7]. 


\subsection{Determining the oversnow vehicle's motion resistance force with the brakes released}

Table 2 contains the results of measurement of the oversnow vehicle's motion resistance force with the brakes released.

Table 2. Results of measurement of the oversnow vehicle's motion resistance force with the brakes released

\begin{tabular}{|c|c|c|}
\hline Oversnow vehicle & $\begin{array}{c}\text { Height of track snow } \\
\text { grip, } \mathbf{~ m m}\end{array}$ & $\begin{array}{c}\text { Motion resistance } \\
\text { force, } \mathbf{N}\end{array}$ \\
\hline RM Buran Leader & 10 & 950 \\
\hline RM Tayga Varyag 550 & 30 & 920 \\
\hline RM Tayga Patrul 800 SWT & 30 & 1105 \\
\hline BRP Lynx Xtrim Commander 800 E-TEC & 44 & 890 \\
\hline Arctic Cat Pantera 7000 XT LTD & 35 & 1370 \\
\hline Polaris 800 Titan Adventure 155 & 45.7 & 2579 \\
\hline
\end{tabular}

\subsection{Determining the oversnow vehicle's motion resistance force with the brakes applied}

Table 3 contains the results of measurement of the oversnow vehicle's motion resistance force with the brakes applied.

Table 3. Results of measurement of the oversnow vehicle's motion resistance force with the brakes applied

\begin{tabular}{|c|c|c|}
\hline Oversnow vehicle & $\begin{array}{c}\text { Height of track snow } \\
\text { grip, } \mathbf{~ m m}\end{array}$ & $\begin{array}{c}\text { Motion resistance } \\
\text { force, } \mathbf{N}\end{array}$ \\
\hline RM Buran Leader & 10 & 2916.6 \\
\hline RM Tayga Varyag 550 & 30 & 2118.2 \\
\hline RM Tayga Patrul 800 SWT & 30 & 3119 \\
\hline BRP Lynx Xtrim Commander 800 E-TEC & 44 & 3670.4 \\
\hline Arctic Cat Pantera 7000 XT LTD & 35 & 4472.6 \\
\hline Polaris 800 Titan Adventure 155 & 45.7 & 4157 \\
\hline
\end{tabular}

\section{Outcomes}

The RM Buran Leader oversnow vehicle's maximum drawbar pull stood at $1850 \mathrm{~N}$.

The RM Tayga Varyag 550 oversnow vehicle's maximum drawbar pull stood at $2750 \mathrm{~N}$.

The RM Tayga Patrul 800 SWT oversnow vehicle's maximum drawbar pull stood at $3000 \mathrm{~N}$.

The RM Vector 551i oversnow vehicle's maximum drawbar pull stood at $3092 \mathrm{~N}$.

The BRP Lynx Xtrim Commander 800 E-TEC oversnow vehicle's maximum drawbar pull stood at $3786 \mathrm{~N}$.

The Arctic Cat Pantera 7000 XT LTD oversnow vehicle's maximum drawbar pull stood at $3841 \mathrm{~N}$ in low gear and $5978 \mathrm{~N}$ in super low gear.

The Polaris 800 Titan Adventure 155 oversnow vehicle's maximum drawbar pull stood at $3590 \mathrm{~N}$.

The RM Buran Leader oversnow vehicle's maximum motion resistance force stood at $950 \mathrm{~N}$ with the brakes released. 
The RM Tayga Varyag 550 oversnow vehicle's maximum motion resistance force stood at $920 \mathrm{~N}$ with the brakes released.

The RM Tayga Patrul 800 SWT oversnow vehicle's maximum motion resistance force stood at $1105 \mathrm{~N}$ with the brakes released.

The BRP Lynx Xtrim Commander 800 E-TEC oversnow vehicle's maximum motion resistance force stood at $890 \mathrm{~N}$ with the brakes released.

The Arctic Cat Pantera 7000 XT LTD oversnow vehicle's maximum motion resistance force stood at $1370 \mathrm{~N}$ with the brakes released.

The Polaris 800 Titan Adventure 155 oversnow vehicle's maximum motion resistance force stood at $2579 \mathrm{~N}$ with the brakes released.

The RM Buran Leader oversnow vehicle's maximum motion resistance force stood at 2916.6 N with the brakes applied.

The RM Tayga Varyag 550 oversnow vehicle's maximum motion resistance force stood at $2118.2 \mathrm{~N}$ with the brakes applied.

The RM Tayga Patrul 800 SWT oversnow vehicle's maximum motion resistance force stood at $3119 \mathrm{~N}$ with the brakes applied.

The BRP Lynx Xtrim Commander 800 E-TEC oversnow vehicle's maximum motion resistance force stood at $3670.4 \mathrm{~N}$ with the brakes applied.

The Arctic Cat Pantera 7000 XT LTD oversnow vehicle's maximum motion resistance force stood at $4472.6 \mathrm{~N}$ with the brakes applied.

The Polaris 800 Titan Adventure 155 oversnow vehicle's maximum motion resistance force stood at $4157 \mathrm{~N}$ with the brakes applied.

Work has been performed in Moscow State Technical University named after N.E. Bauman with financial support of the Russian Ministry of Education under Agreement №14.577.21.0272 (Work unified indicator: RFMEFI57717X0272)

\section{References}

1. V.S. Makarov, D.V. Zezyulin, V.V. Belyakov, Snow as a roadway for vehicles, Int. J. of Appl. and Fundamental Research, 4, pp. 21-24 (2014)

2. V.V. Belyakov et al., Mobility of ground transport-technological machines, Proceedings of NSTU. R.E. Alekseeva, 4, pp. $72-77$ (2013)

3. V.A. Grushnikov, The use of snowmobiles in Russia, Autotransport enterprise, 2, pp. 49-52 (2006)

4. GOST R 50944-2011 Snowmobiles, Technical requirements and test methods

5. F.F. Mukhamadyarov, A.I. Chuprakov, S.A. Romanov, The Construction of Snowmobiles (Textbook, Kirov, 2016)

6. D. Vail, Governing snowmobilers in multiple-use landscapes: Swedish and Maine (USA) cases, Ecological Economics, v. 48, 4, pp. $469-483$ (2004)

7. A.S. Diakov, A.Yu. Zakharov, V.E. Klubnichkin, E.E. Klubnichkin, A.B. Kartashov, Experimental estimation of high-speed and braking properties of domestic production of snowmobiles, Proceedings of NSTU. R.E. Alekseeva, 1, pp. 156-164 (2018) 